\title{
CIVIL LIABILITY OF THE MENTALLY DISORDERED PEOPLE
}

\author{
Mahdis Riahy ${ }^{1}$ \\ Mahdi Esmaeile ${ }^{2}$
}

\begin{abstract}
Nowadays, mental disorders are some of the most common diseases in our societies. In most cases mentally disordered people will be having problems with the environment which they live, people around them and even themselves; with the probability of causing damage. The question is does the mentally disordered individual counts responsible for the consequences of his actions or not? If yes, then what type of liability is on his burden and who is responsible for redressing the damages? In any case, which a person is forced to redress another individuals damage he has civil liability against the injured party. Civil liability is a rational and jurisprudential principle, and also a legal maxim that guaranties remedies for faults of individuals inside a contract or any damages done by the acts of individuals outside of a contract. Considering the legal protection Provided for the incapacitated; liability
\end{abstract}

of incapacitated individuals is an important subject of civil and criminal law. Since the sinister intention is essential for criminal liability; the minor and the insane do not have any criminal liability but insanity and minority are not among the disclaimers of civil liability. In some legal systems such as "Common Law" Civil liability of the incapacitated individuals and their wardens is under the rule of general civil liability regulation. However, in Iran I.R. liability of the incapacitated is clearly recognized by the article " 1216 " of Iranian Civil Code. In respect of the above, we will be researching about the psychotic and mentally ill individuals and their liability in Jurisprudence and Iranian Case Law. Point of this research is to clarify the conditions of the insane and mentally disordered in Iranian Law and the support given to them by the Legislators.

\footnotetext{
${ }^{1}$ Department of Law, Ayatollah Amoli Branch, Islamic Azad University, Amol, Iran. Email: Mahdis.riyahi1367@gmail.com.

${ }^{2}$ Professor, Department of Law, Ayatollah Amoli Branch, Islamic Azad University, Amol, Iran. Email: Dresmaeli@yahoo.com.
} 
Keywords: Civil Liability, Insane, Mentally disordered, Incapacitated, Redressing of Damages, Compensation, Remedy

\section{Introduction:}

Like many other branches of Law, Civil liability comes from Roman law; Since Roman law begins in 8th century BC and ends in 6th Century AD at the time of Byzantine Emperor "Flavius Lustinus Augustus". For 13 centuries the Roman law had developed from early stages to its peak in the 6th century. In early times every human who faced damage or harassment would have found his remedy in personal revenge. Main goal of these actions where to make an example for rest of the society, leading to more bloodshed due to more hatred among families; later on, a more temperate reaction was used in which the damaged party had the right to choose between personal revenge or a remedy for the damages; In fact head of a family would have bought the damaged party's right of revenge with a sum of money. In the late stages asking for remedies went under a regulation known by common people of a society and then these regulations became written principles. One of the oldest written laws is "Leges
285

Duodecim Tabularum" that a part of it is related to remedies and punishments. In Iran, Civil Code (Also known as The Mother Code) began its existence with the enactment of its first volume about Transactions and bargaining in 1928 an then its second and third volume about Personal Status and rules of evidence in 1933 and 1935. Iranian Civil Liability Act was passed by Iran National Parliament in 1950 with 16 articles with a glance at western laws especially Swiss laws of obligation and Iranian case law at that time. Liability in its legal definition is a mandatory or voluntary obligation of one individual against another individual (whether financial or non-financial) and civil liability is yet one of the most complicated branches of law and still needs a resolution from Jurists and professors of law. It is a logical principle that the aggressor party pays something as compensation to the aggrieved party. Generally, every transaction that happens between people is based on this principle. In current laws, the laws of civil liability supervise the responsibilities of any actions. Anyone who could be counted as criminal liability is also responsible for the consequence of his actions; that means he has to pay compensation for 
the results of his crime. Civil liability talks about a situation in which the injured party receives a remedy for the injury from the aggressor party. Incapacitated individuals cannot be held criminally liable due to the lack of Mens rea in their actions but civil liability is not based on a person's intent, so current laws count all types of incapacitated individuals responsible for their actions. When an incapacitated individual causes damage, the first question that comes to mind is: "who should redress the damage?" And "is it basically possible to ask remedies for acts of incapacitated or not?" These are the questions that civil liability was created to answer. In the past there were doubts about the matter that since the incapacitated is not responsible for his action he cannot be held liable for the damage he has done; but nowadays, due to Expenditure of civil liability's domain, there is no doubt that no damage should remain without remedy. Every time someone's act or omission causes damage he is obligated to redress the damage.

\section{1- Goal of Civil Liability}

The main Goal of civil liability or tortious liability is to redress the damages of the injured party, or in another word, to safeguard the privacy rights of individuals. Civil liability has functional goals in association with the aggressor, the aggrieved, and society. Redressing as an amount of money is the main goal of civil liability, however, it's not the only goal. Abatement of aggression against the plaintiff and preventing future injuries are some of the goals. Civil liability can play an important role in preventing the aggressor from future aggression and it can take away the sense of revenge in the aggrieved person. In association with the society, civil liability supervise the rights and freedom of people and acts as leverage in dealing with potential aggressors.

\section{2- Elements of Civil Liability}

\section{1- Damage and Loss}

Damage is the first element in creating civil liability and it has taken these meanings in the Law:

- $\quad$ Damage or injury against a person's life such as Murder, Manslaughter, Self-harm, Battery etc.

- $\quad$ Rape, Ravishment and violation against a person's body 
- Discrediting a person, encroachment of a person's honor,

- $\quad$ Destroying or defecting of another's property

- $\quad$ Preventing someone an available or expected profit

What we mentioned above are almost the things mentioned in article 10 of Iran's civil liability act, 1950. Damage and loss caused against a human being cannot be limited to monetary damages since there are moral damages and unliquidated damages, incomparable with money. From Iran's civil liability act, 1950:

“Article 10: Anyone who's personal or family credit has been injured, can bring on action against the aggressor and ask for compensation for both his actual and moral damages. In case the aggressor's fault is proven and with attention to the type of damage; the court can give a verdict to force the aggressor to apologize or to insert the verdict on newspapers."

In addition with article 10 of civil liability act, there is another way that the injured party can ask for redressing his losses with asking the court to stop or seize the operation responsible for the injury, mentioned in article 8 of civil liability act.

Damage that creates liability should have three characteristics:

1.Damage must be real

2.Damage must not be redressed

3. Damage must be direct, which means damages with too many mediators are not redressed

\section{2- Harmful Act or omission}

The second element for creating civil liability is the harmful act that must be either unconventional, abnormal or prejudicial to public order and counted improper by the law. However, there are some exceptions such as self-defense, coercion, the verdict of law, etc.

\section{3- Causality relationship between harmful act and damage}

The injured party must prove the causality relationship between the action and injury. Until this relationship is not proved, we cannot say that action is a harmful one. For an action to be counted harmful, we must prove that without that action no injury would have happened. So if we prove that the culprit could not do anything to prevent the injury (such as force majeure or any 


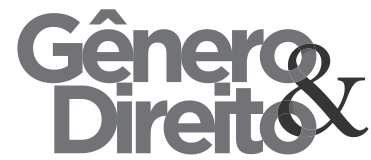

Periódico do Núcleo de Estudos e Pesquisas sobre Gênero e Direito

Centro de Ciências Jurídicas - Universidade Federal da Paraíba

V. 8 - No 03 - Ano 2019

ISSN | 2179-7137 | http://periodicos.ufpb.br/ojs2/index.php/ged/index other intervening cause) it would clarify that fault of the defendant is not the cause of damage.

\section{3- Definition of Mental Disorder}

Mental Disorders are a group of illnesses that affect a person's mind and action making the victim incapable of doing certain actions or disrupt his thoughts, feelings, and actions in daily life. Cause of mental disorders are not clearly known, but genetic problems, trauma, high levels of stress and a person's interactions with others are some of the reasons leading to mental disorder.

\section{4- Classification of Mentally sick} people in Iran's civil code

\section{1- Definition of incapacitated} Individual

Legal definition of an incapacitated individual is: A person who do not have capacity so some jurists have defined incapacitation as:

"Prohibiting a person from independently running his daily affairs, specifically legal affairs by the verdict of law"
Some of Islamic Jurisprudents such as "Mohaghegh Hellie" and most of the jurists have limited incapacitation to financial affairs. But Incapacitation has its effects on some other matters such as right of retaliation or divorce, so we cannot limit incapacitation to financial affairs only. But financial affairs have been on the center of jurist's focus.

\section{2- Type of incapacitated individuals under protection of law}

Incapacitated Individual is a person who has been banned from some legal actions due to his mental state.

\subsection{1- The minor}

Minor means little or small. In its legal definition minor means a person who is under age of puberty?

Article 1207 of Iran's civil code counts the minor, Insane and immature as incapacitated individuals.

Article 1210 of civil code describe that puberty age for male is 15 years of age and for female is 9 years of age and after the mentioned age a person is not incapacitated anymore.

There are two types of minor, discerning minor and undiscerning minor. Undiscerning minor lacks the 
power to understand right or wrong but a discerning minor can differ what's good and what's bad so in some cases, a discerning minor can have a legal will. Civil code of Iran does not talk about a certain age for undiscerning minor to become discerning minor but in Imamie jurisprudence some talk about the age of six or seven years old.

\subsection{2- The Immature}

Article 1208 of Iranian civil code describes Immature as an individual who cannot make logical decisions about his property and possessions. Unlike the rest of the incapacitated individuals, immature's incapacity is only in financial affairs and he has the capacity for rest of his legal affairs. To clarify between mature and immature we must look at their ability to understand profit and loss, not ability to understand right and wrong.

\subsection{3- The Insane}

In all the laws, in order to disclaim a person from his liabilities, we must prove his lack of understanding right and wrong. Insanity means lack of judgment and understanding due to mental problems and in its legal definition insanity means lack of understanding the difference between right and wrong, good and bad, profit and loss. Insane is a person who has such a mental disorder that he cannot defend his rights in society. Article 1211 of civil code says that "insanity at any level results in incapacity" in order to protect their rights, article 1207 of civil code bans insane from possessing his property and financial rights. Article 1217 of civil code puts the responsibility of an insane person's property and financial right on the burden of their parents or wardens.

\section{5- Basis of incapacitated person's liability}

Considering the fact that incapacitated person does not have a criminal liability we say that this will not disclaim civil liability because in civil liability main focus is to redress damages.

\section{6- The complexity of issue from legal point of view}

Civil liability of insane is a hard matter to think about since non-legal consideration behind the matter won't let us give a clear and definite viewpoint on 
the subject. When it comes to damage done by actions of an insane individual we face with two victims. One side is a person who has suffered injury and other side is an insane person who is a victim of his mental illness. Redressing the damage cannot be different based on a person's state of mind, because if we disclaim the insane person it means we have left the injured party alone to suffer consequence of another's actions. Also if we hold the insane liable for his action (which we do by verdict of law) we have left him alone to suffer actions he had no intent to do.

Iran's civil code clearly hold insane people liable for their actions in article 1216:

"Anytime an insane, immature or minor individual causes a damage he is liable" 3

Article 7 of Iran's civil liability act takes on a more temperate reaction but in case of mentally disordered people it seems there is nothing else but emphasizing civil code's verdict on the matter.

\footnotetext{
${ }^{3}$ Word "Damage" here refer to monetary damage only. Because moral damage often has criminal basis but moral damage caused
}

The question is does the word "Liable" contain both deliberate destruction and indirect destruction or as some say it only contains deliberate destruction? To answer this question we must find the basis of article 1216 in Iranian civil code

\section{7- Causes of civil liability in Iran's civil code}

\section{1- basis of article 1216}

Basis of civil liability in the Iranian civil code is 4 actions: deliberate destruction, indirect destruction, usurpation, and vindication. Usurpation has specific regulations and in vindication, damage or injury is not the cause of civil liability. So in order to understand article 1216 we must study the concept of deliberate and indirect destruction and find out if we should prove the fault of the aggressor in indirect destruction in order to hold him liable or like deliberate destruction, it does not matter.

\subsection{1- Necessity or lack of necessity of} fault in indirect destruction

by immature holds him liable and it can cause liability for incapacitated person's warden 
Deliberate destruction is wasting or destroying a person's property by direct act of another person and fault or intent of the aggressor is not a condition. Iran's civil code describes the matter at article 328:

"Anyone who destroys another person's property is liable and must give the same property or the price of it as compensation. Whether he had intentions to destroy the property or not. Whether the property itself is destroyed or its benefits. And if he damages the property must pay the difference between whole property and damaged property price."

About indirect destruction there is no such a certainty between jurists. Legislator has not talked about whether fault or intention are among conditions of liability from indirect destruction or not; in article 331 it says:

"Anyone who indirectly causes the destruction of another's property must give the same property or its price as compensation and if the property is damaged must pay the difference between whole property and damaged property's price"
This lack of clarity in civil code is the source of disagreement between jurist bout whether the fault is a condition in indirect destruction or not. Based on jurisprudential backup and concept of the above article, some say that proving the causality relationship is enough and fault is not a condition in indirect destruction. This viewpoint has good reasoning power based on Islamic narratives and traditions, words "fault" or "intent" has not been mentioned by Islamic jurisprudents on the cases about indirect destruction. Also, the Evolution of civil law has had a tendency to make civil liability a general liability instead of personal liability. Cases such as liability from manufacturing defect or children's liability in French laws are an example of this matter. Even those who support fault in indirect destruction admit that in some cases there are so many remote or intervening causes that general liability basis is the only solution to guaranty remedies for the damage. It seems that in Islamic jurisprudence, the main goal is to guaranty the remedies for the injured party. Anyway, we cannot adopt the Islamic system with one of the new civil liability theories. In jurisprudential texts, the concept of causality relationship is very close to personal liability basis and 
even if we can barely accept the general liability basis in Islamic system for obvious reasons we cannot accept it in Iranian system of law. In order to compare Islamic system with Iran's law we must take a look at other articles about indirect destruction and deliberate destruction to see the verdict in other cases. In article 329 and 330 of civil code we see other examples of deliberate destruction and same as article 328 fault or intent are not conditioned. But in articles $332-335$ different examples of indirect destruction create civil liability only if fault or intent of the aggressor is proven. On the other hand, proving the causality relationship is not easy in indirect destruction and we must accept that the fault or intent of aggressor is a proof of causality relationship. In respect of what we discussed above, it seems that Iran's civil code has clear intentions on conditioning fault or intention in civil liability based on indirect destruction and verdict of article 328 is a definition of "indirect" and its purpose is to clarify the difference between deliberate destruction and indirect destruction.

\subsection{2- Possibility attribute the fault to} the mentally disordered individual
Some still believe that liability in indirect destruction is strict liability but with the evidence mentioned above it is clear that liability from deliberate destruction is strict liability and in indirect destruction we face fault-based destruction. If we support personal fault or general fault ideas we may give different opinions on the concept of article 1216. But the most reasonable viewpoint in Iran's law says that article 1216 intents to clarify that lack of judgment in insane and minor will not disclaim their liability against the injured party and they must be held liable same as a healthy adult individual; whether liability is strict or fault-based. This contains liability from deliberate or indirect destruction and liability from driving accident and so on. But that's not everything we have on the table. Article 1216 is not the only article with a verdict about incapacitated individual's liability. In Iran's civil code we see that if the insane or minor's actions are results of a normal individuals actions they will not be held liable. Whether the adult is a remote cause or else he is counted procuring cause and will be held liable by verdict of law. In French law judge takes the same look to an insane or 
minor person that he takes at a healthy adult and if harmful act is related to both he will hold both of them responsible for paying compensation to the injured party but in Iran's law an insane person is believed to be merely a tool at the hands of sane and adult individual so he will be free of any liability. In article 1215 of Iran's civil code we see:

"If anyone puts a property under possession of an undiscerning minor or an insane person, the minor or insane will not be liable for destruction or damage done to the property"

Some believe that verdict of article 1215 is limited to the action of a person against himself but the word "a property" is general and does not mean a person's own property. So the result of mixing verdict of articles 1215 and 1216 is when an insane or minor act alone and independently he is liable for his actions but when a capacitated person comes along in the action insane or minor will not be responsible for their actions, sane or adult person will be liable based on being the procuring cause or his action against himself. But what if someone puts a property under the possession of an insane but has no knowledge of his insanity? Under general regulations of law, we must say that destruction or damage done to the property is the result of insane's action but in order to disclaim the sane person's liability, he must prove his lack of knowledge to the insanity of the aggressor otherwise sane individual will be liable. In general, it seems that Iran's law do not see minor and insane's liability as a fault-based liability and their liability comes from a comparison between their action and reasonable, normal individual actions.

\section{8- Periodic insanity and its effects on financial rights}

Total insanity is a state of mind when a person's mind is never working right and in all conditions signs of his insanity is clear. An insane person is never able to make correct decisions due to always clashing with his mental disorder. However periodic insane person is not always insane. Sometimes he gets control over his mind understanding the rights and wrong or in some cases he only loses control over his mind in special conditions or environments. Insanity prevents a person from making rational decisions about his financial rights but in time when a periodic insane has control over 
his mind he can make independent decisions about his rights and properties. But what about when he loses control over his mind and becomes insane? In this case we say "insanity at any level is cause of incapacity" so he cannot control his property or use his financial rights.

\section{9- Act of periodic insane about his}

\section{future property}

Future properties such as fruits of trees or rent of a house etc. are counted the same as actual property and destroying them is cause of liability. But what is the status of a periodic insane individual's contract about his future property that is signed in his time of insanity? It looks like such a contract is not legally effective but when the periodic insane gains his sanity he can confirm his late decision and make the contract valid otherwise the contract is nullified.

\section{0- Periodic insane legal action in his non-financial rights}

It is clear that in his times of sanity he is like a normal person in using his right but in times of insanity, his lack of control over his mind does not prevent a periodic insane from his capacity to have his right however he cannot use those rights. For example inheritance is a non-financial right with financial effects. A periodic insane can inherit property but he cannot use his right to sell the inherited property unless he is in sanity status.

\section{1- Capacity}

Capacity is the legal ability to have rights or to use rights. The capacity to have rights is called capacity of enjoyment and capacity to use rights is called capacity of vindication. Article 210 of Iran's civil code describes the necessity of capacity in contract parties and article 190 describes capacity as a condition of contracts validity. Incapacity can be general like the incapacity of insane or minor or can be specific like incapacity of legal warden to transact with person under his ward. Article 210 talks about general incapacity. From Iran's civil code:

"Article 211: for the contract parties to have capacity, they must be mature, sane and past puberty age."

"Article 345: Both buyer and seller must be capacitated to form contracts and have 
capacity to possess object of sale and price."

So, insane person cannot form any contract by himself but periodic insane can participate in contracts in his times of sanity.

\section{1- Capacity of possession in periodic insane}

Word "Capacity of possession" in article 345 refers to when a property is seized by verdict of court and owner cannot possess it as a normal property. There is no specific verdict in law that prevents a periodic insane from possessing his properties. But a total insane person needs confirmation of his warden in order to participate in a contract and possess the object of sale or price.

\section{2- Civil liability of insane}

Now that we are sure about civil liability of insane individuals, there are three different assumptions about liability:

First, is when an insane person has caused damage without a warden or with a warden who has made no fault or mistake in protecting the insane? This is a case of article 1216 of the civil code and the damage will be redressed from insane's property and if he has no property the aggrieved party's right will remain until the insane aggressor has something to pay him. Second is when the aggrieved party is responsible for putting his property under insane's possession and it's a case of article 1215 of the civil code. The aggrieved party is liable for redressing his own damage. Also there is a sub-assumption of the above in which the aggrieved party provokes the insane to damage his property and in this case he is procuring cause of damage and again the insane is not liable the Third case is when insane has caused damage but he had a warden who was supposed to protect him from doing so and made fault in doing his job. This is a case of article 7 of Iran's civil liability act .1950 in which the warden is held liable unless he does not have enough money or property to redress the damages. In this case, the rest of the damage will be redressed from insane's property.

\section{3- Civil liability of wardens of minor} or insane 


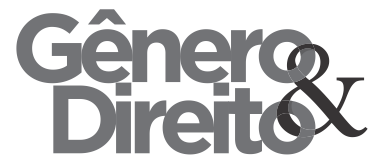

It is a legal maxim that everyone must be responsible for results of their own actions but liability based on another's actions is an exception created to support the injured party in redressing his injuries. Article 7 of civil liability act does not mention immature because as immature has criminal liability so does have civil liability for his action. Guardianship of immature is only for his financial affairs so his warden has no responsibility for rest of his actions.

\section{1- Basis of warden's liability}

As we mention earlier, there are three necessary elements in order to create civil liability: Damage, Harmful act, causality relationship

\subsection{1- Damage}

It is necessary that a damage is done. Whether an action is a crime or not, unless it causes damage it won't create civil liability.

\subsection{2- Harmful Act of minor or insane}

In order to create civil liability someone's action must have caused the

\section{6}

damage. (Actus dei nemini nocet) Article

1 of Iran's civil liability act says:

"Anyone who intentionally or out of carelessness or fault or without legal permit causes damage to another's property, will be held liable for redressing the damage he has caused"

So anyone who has no fault in damaging another's property is not liable and that includes minor and insane. Although it seem that except for deliberate destruction and driving accident in rest of occasions fault is a condition of civil liability in Iran's law, liability from act of minor or insane must be added to these exceptions.

\subsection{3- Causality relationship}

If warden leaves his duties to protect the insane (or minor) or commits an action that provokes the insane and he causes damage to other people this damage is a result of warden's fault. So fault of warden proves the causality relationship between him and the damage in need of redressing.

\section{2- A critique of article 7 of civil} liability act 
There is a conflict between article 7 and what we have mentioned above. While we hold the warden responsible, article 7 lets the damage to be redressed from insane's property. The main problem is that article 7 holds warden as a liable party while article 1216 of civil code says the insane himself must be held liable. Article 7 could have been a perfect legal sanction in order to prevent the wardens from shirking their duties against the insane under their ward if it had created contractual liability for wardens and recognized them liable by the contract of guardianship. It is not logical that we recognize wardens liable but let them redress the damage from insane's property for two obvious reasons: First, the liability of wardens, in this case, is not based on them being procuring cause since they have no intention about their under ward's action. Second, the legislator wanted to give a scape rout to the warden who will be under economic pressure if he pays all the remedy but this does not match justice of the law. If anyone deserves leniency in this matter it's insane who is under the protection of law, not the guilty warden who has failed in his duties. It seems that legislator's goal from this article is to guaranty redressing of injured party's damages but it has chosen a wrong way by combining two completely different liabilities.

\section{4- Conclusion and suggestions}

Considering the diseases causing mental disorders, it seem any mental disorder that leads to loss of control over mind and lack of judgment about right and wrong will incapacitate a person from capacity mentioned in article 190 of civil code, therefor nullifying or discrediting the insane person's contracts. Any beneficiary party can ask the court to check if a party of a contract had been insane at the time of forming the contract.

Insane has no criminal liability but his civil liability will not be disclaimed under any circumstances.

Liability of minor or insane individual's warden is an exception of personal liabilities principle.

Article 7 of civil liability act has based warden's liability on their fault and professors of civil law believe that plaintiff must prove the fault of warden against the court. In order to prevent article 7 from repeating article 1 it is best that judicial precedent accept the fault of 


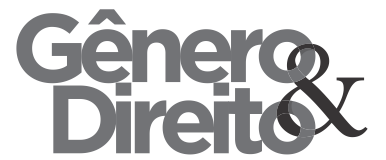

Periódico do Núcleo de Estudos e Pesquisas sobre Gênero e Direito

Centro de Ciências Jurídicas - Universidade Federal da Paraíba

V. 8 - No 03 - Ano 2019

ISSN | 2179-7137 | http://periodicos.ufpb.br/ojs2/index.php/ged/index warden as a default rule because such a thing is accepted in laws of France, Germany and Switzerland(Swiss) which inspired the authors of Iran's civil liability act

Article 7 of civil liability act must be changed due to its conflict with article 1216 of civil code and in order to do so we must make liability insurance mandatory for wardens as a legal sanction.

\section{References}

\section{A) Books}

Arshadi, Aliyar, 1384, An explanation Iran's civil law, Saye roshan publication, first publication, Tehran

Ardebili, Mohammad, 1386, General criminal law, $1^{\text {st }}$ volume, Mizan publication, $14^{\text {th }}$ publication, Tehran

Emami, Seyyed hasan, 1340, Civil law, first volume, Eslamiye publication, $71^{\text {st }}$ publication, Tehran

Ansary, Masoud, 1340, Encyclopedia of civil law, $3^{\text {rd }}$ volume, Mehrab publication, Tehran
Barikloo, Alireza, 1387, Individuals and their legal protection, Majd publication, first publication, Tehran

Jafari Langrodi, Mohammadjafar, 1346, Terminology of law, Ganje danesh publication, first publication, Tehran

Haeri, Ali, 1376, Explaining Iran's civil code, ganje danesh publication, Tehran

Hossein nejad, Hosseingholi, 1370, civil liability, Cultural and collage publication of shahid beheshti, first publication, Tehran

Daliri, Mohammadsaleh, 1373, General criminal law, $3^{\text {rd }}$ volume, Daad Publication, first publication, Tehran

Soltani nejad, Hedayatollah, 1380, Basis of civil liability in intellectual damages, Nor as-saghalain publication, Tehran

Shahidi, Mahdi, 1377, Creating contracts and obligations, $1^{\text {st }}$ volume, Majd publication, Tehran

Sadeghi, Mohammadhadi, 1386, Crimes against individuals, Mizan Publication $10^{\text {th }}$ publication, Tehran 
Safayie, Seyyed hasan, Qassemzadeh, Seyyed Morteza, 1395, Civil laws of incapacitated individuals, Samt publication, Tehran

Taheri, Habibollah, 1376, Civil law 2, $1^{\text {st }}$ volume, Islamic publication office, $2^{\text {nd }}$ publication, Qom

Amid Zanjani, Abbasali, 1382, Causes of liability, Mizan Publication, $1^{\text {st }}$ publication, Tehran

Feiz, Alireza, 1373, Basis of Islamic principles and jurisprudence, Tehran university publication, $6^{\text {th }}$ publication, Tehran

Qassemzadeh, Seyyed Morteza, 1378, Basis of civil liability, Daadgostar publication, $1^{\text {st }}$ publication, Tehran

Katozian, Nasser, Legal Acts of Contracts, $2^{\text {nd }}$ volume, Publication Company, Tehran

Katozian, Nasser, 1381, Preliminary course of civil law: Legal Events, Publication Company, Tehran
Katozian, Nasser, 1385, Civil code in current legal order, Mizan Publication, $13^{\text {th }}$ publication, Tehran

Lodessaran, Michael, 1375, Civil liability, Translated by Dr. Mohammad Ashtari, Hoghoghdan Publication, Tehran

Madani, Seyyed jalal od-din, 1385,Civil law: Investigation the profile of individuals and confidants, $7^{\text {th }}$ volume, Paydar publication, $1^{\text {st }}$ publication, Tehran

Moein, Mohammad, 1350, Moein Dictionary, Amirkabir publication, $1^{\text {st }}$ publication, Tehran

Moein, Mohammad, 1375, Persian Dictionary, Amirkabir publication, $9^{\text {th }}$ Publication, Tehran

B) Articles and Thesis

Rezapoor, Sarah, Autumn of 1390, Civil liability of insane in Iran's law

Zaker Hosseini, Mohammadhadi, 1394, A research in liability of incapacitated and their wardens, 


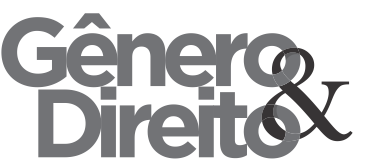

Periódico do Núcleo de Estudos e Pesquisas sobre Gênero e Direito

Centro de Ciências Jurídicas - Universidade Federal da Paraíba

V. 8 - No 03 - Ano 2019

ISSN | 2179-7137 | http://periodicos.ufpb.br/ojs2/index.php/ged/index

Elmi, Mohammadreza, Qobadi, Kaveh,

C) Websites

Volume 10, Issue 4, Winter of 1393 ,

Legal-sindblogra.com

Domain of Insanity in Jurisprudence and

Wikifegh.ir

law, jurisprudential researches

Moradzadeh, Hasan, Volume 41, Issue 2, 1390, Collective Responsibility: A just solution in civil liability domain, Quarterly journal of law, Faculty of law and political sciences

Doroodian, Hasanali, issue 36, spring of 1376, civil liability from acts of individuals under guardianship, Tehran University's faculty of law and political sciences

Azarbadegan, Hosseinali, Winter of 1380, Classification of mentally disordered individuals and their verdicts in "Mohaghegh Naraghi" view

Asgharzade, Aminsafih, Shahmohammadi, Davood, issue 2, Spring of 1378, Collection of laws about psychotic patients in Iran

Dr. Hosseinabadi, Amir, 1385, investigating article 7 of civil liability act Badini, Hossein, Winter of 1383, Goal of civil liability, Law and politics, Issue 66, Tehran 